\title{
MARIE-SOPHIE ARMSTRONG, "L'Assommoir" ou les déboires du premier objet
}

\section{Maria Emanuela Raffi}

\section{(2) OpenEdition}

\section{Journals}

\section{Edizione digitale}

URL: https://journals.openedition.org/studifrancesi/44143

DOI: 10.4000/studifrancesi.44143

ISSN: 2421-5856

\section{Editore}

Rosenberg \& Sellier

\section{Edizione cartacea}

Data di pubblicazione: 1 juin 2021

Paginazione: 238

ISSN: 0039-2944

\section{Notizia bibliografica digitale}

Maria Emanuela Raffi, «MARIE-SOPHIE ARMSTRONG, "L'Assommoir" ou les déboires du premier objet», Studi Francesi [Online], 193 (LXV | I) | 2021, online dal 01 juillet 2021, consultato il 15 octobre 2022. URL: http://journals.openedition.org/studifrancesi/44143; DOI: https://doi.org/10.4000/studifrancesi. 44143

Questo documento è stato generato automaticamente il 15 octobre 2022

\section{(c) (i) (9)}

Creative Commons - Attribuzione - Non commerciale - Non opere derivate 4.0 Internazionale - CC BY NC-ND 4.0

https://creativecommons.org/licenses/by-nc-nd/4.0/ 


\section{MARIE-SOPHIE ARMSTRONG,}

\section{"L'Assommoir" ou les déboires du premier objet}

Maria Emanuela Raffi 


\section{NOTIZIA}

MARIE-SOPHIE ARMSTRONG, "L'Assommoir" ou les déboires du premier objet, “Australian Journal of French Studies" 56, Issue 3, December 2019, pp. 271-286.

Ispirandosi alle teorie psicanalitiche di Mélanie Klein e prendendo quindi come fondamentali le immagini legate al seno materno, molto presenti nei Rougon-Macquart sia in modo letterale che metaforico, M.-S. Armstrong si propone di dimostrare che «l'univers prolétaire de L'Assommoir offre des similarités frappantes avec l'univers fantasmatique des premières relations d'objet», secondo lo schema «schizo-paranoïde»: idealizzazione della figura materna, distruzione e alla fine matricidio. Seguendo questa linea interpretativa, l'alambicco si configura come seno, che nutre e avvelena, ma anche la lavanderia di Gervaise e la stessa protagonista femminile appaiono intrisi di allusioni all'immagine del «nourisson comblé par le sein maternel». Al piacere del nutrimento si accompagna tuttavia l'istinto invidioso e distruttivo impersonato da Nana e soprattutto da Coupeau, che più volte, nel corso del romanzo, presenta un modo di nutrirsi e di godere molto vicino alla distruzione e allo svuotamento dell'oggetto amato, come nella scena del «repas de fête de Gervaise». L'avidità di Lantier costituisce, infine, l'ultimo elemento del percorso fantasmatico tracciato dall'A., mostrando il corpo materno dilaniato e distrutto e realizzando quindi il completamento, insieme a quello sociale, di un percorso psichico dell'eccesso. Accanto alla paura per le forze che possono distruggere la società francese, «les excès du corps ouvrier», Zola dà quindi spazio anche alla paura che caratterizza «le psychisme archaïque de tout individu». 